\title{
SPATIAL STRUCTURE OF PLEUROTHALLIS, MASDEVALLIA, LEPANTHES AND EPIDENDRUM EPIPHYTIC ORCHIDS IN A FRAGMENT OF MONTANE CLOUD FOREST IN SOUTH ECUADOR
}

\author{
Lorena Riofrío ${ }^{1,3}$, CARlos Naranjo $^{1}$, José M. Iriondo $^{2} \&$ Elena Torres $^{2}$ \\ ${ }^{1}$ Universidad Técnica Particular de Loja, San Cayetano Alto s/n, Loja, Ecuador \\ ${ }^{2}$ Universidad Politécnica de Madrid, Ciudad Universitaria s/n, E-28040 - Madrid, Spain \\ ${ }^{3}$ Author for correspondence: mlriofrio@utpl.edu.ec
}

KEY WORDS: altitudinal range, colonization, phorophyte specificity, phorophyte trunk diameter, seed dispersal, spatial patterns

Orchids are the most diverse family of vascular plants in Ecuador with 228 genera and nearly 4000 species. More than $60 \%$ of these species are epiphytes, being Pleurothallis R.Br., Epidendrum L., Lepanthes Sw. and Masdevallia Ruiz \& Pav., with $472,358,314$ and 226 species respectively, some of the genera with greater number of epiphytic orchids (Dodson 1994-2003).

Although Ecuador is among those countries with the highest orchid biodiversity in the world, it also has one of the highest rates of deforestation: $1.2 \%$ of the country's forests are lost each year (FAO 2005). Extensive deforestation practices currently taking place pose a major threat for the survival of these orchids as they are greatly dependent on the environmental conditions of the forests that sustain them, and the host trees (phorophytes) on which they grow. Thus, understanding of orchid-phorophyte interactions, as well as the patterns of spatial distribution and colonization in secondary succession forests regenerated after deforestation, is essential for the in situ conservation. Nevertheless, few studies have been conducted in this field, and scientific basis supporting population reinforcement or reintroduction actions is scarce.

The purpose of this study is to assess the spatial distribution of epiphytic orchids of the above-mentioned genera in an Ecuadorian fragment of secondary montane cloud forest to infer patterns of seed dispersal and colonization. In addition, the effects of phorophyte identity and size on orchid establishment are analyzed. Specifically the questions posed are: Do the distributions of Pleurothallis, Epidendrum, Lepanthes, and Masdevallia plants vary in the altitu- dinal range of the fragment studied? Are there specific patterns in their spatial distribution resulting from seed dispersal characteristics? Do plants of these orchids exhibit any preference over the trees where they grow? Does phorophyte trunk diameter affect the establishment of these orchids? The results presented, although preliminary, provide useful information for orchid management plans.

The study was carried out in a fragment of regenerated forest located on the Loja-Zamora Chinchipe road, on the border of Podocarpus National Park (southern Ecuador). The age of the forest is about 30 years old, and it is characterized by a steep slope (51\%), with trees 5-8 $\mathrm{m}$ high and lianas that are over $10 \mathrm{~m}$ long. Mean annual precipitation is $2700 \mathrm{~mm}$, and annual mean temperature is $15.5^{\circ} \mathrm{C}\left(14.4-17.5^{\circ} \mathrm{C}\right)$.

A total of nine $10 \times 10 \mathrm{~m}$ plots were established at 2200, 2230 and $2250 \mathrm{~m}$ a.s.l. (three plots in each altitude). All trees (including fern trees), shrubs and lianas of diameter at breast height (DBH) over $1 \mathrm{~cm}$ were determined at the genus level, measured and mapped. The census included 1025 vascular plants belonging to more than 70 different genera. Miconia Ruiz \& Pav. (148 trees), Nectandra Rol. ex Rottb. (65 trees), Clusia L. (59 trees), Elaeagia Wedd. (59 trees) and Psammisia Klotzsch (56) were the most frequent genera.

Presence and abundance of all orchids occurring in the first $3 \mathrm{~m}$ height were also recorded. In this zone, which corresponds to zone 1 of Johansson's scheme, the microclimatic conditions are relatively constant (Johansson 1974). In total 2798 orchids belonging to 12 genera were identified. Although it is difficult to make comparisons between different researches 
TABLE 1. Distribution of Epidendrum, Pleurothallis, Lepanthes or Masdevallia orchids on their respectives host trees in a secondary montane cloud forest in South Ecuador. For each orchid genus, frequency of host trees (first column) and frequency of orchid individuals on the different host tree genera (second column) are shown.

\begin{tabular}{|c|c|c|c|c|c|c|c|c|}
\hline \multirow[t]{2}{*}{ Host genus } & \multicolumn{2}{|c|}{ Epidendrum } & \multicolumn{2}{|c|}{ Pleurothallis } & \multicolumn{2}{|c|}{ Lepanthes } & \multicolumn{2}{|c|}{ Masdevallia } \\
\hline & $\mathrm{n}^{\circ}$ of trees & $n^{o}$ of orchids & $\mathrm{n}^{\circ}$ of trees & $n^{0}$ of orchids & $\mathrm{n}^{0}$ of trees & $\mathrm{n}^{\circ}$ of orchids & $\mathrm{n}^{\circ}$ of trees & $\mathrm{n}^{\circ}$ of orchids \\
\hline Abuta Aubl. & 1 & 3 & - & - & - & - & - & - \\
\hline Alchornea Sw. & - & - & 1 & 18 & - & - & - & - \\
\hline Alzatea Ruiz \& Pav. & - & - & 1 & 1 & - & - & - & - \\
\hline Aniba Aubl. & - & - & 1 & 2 & - & - & - & - \\
\hline Anthurium Schott & 1 & 7 & - & - & - & - & - & - \\
\hline Ardisia Gaertn. & 2 & 10 & 1 & 5 & - & - & - & - \\
\hline Axinaea Ruiz \& Pav. & - & - & 2 & 2 & - & - & 1 & 2 \\
\hline Calyptranthes Sw. & 1 & 1 & 3 & 16 & - & - & - & - \\
\hline Cinchona L. & 1 & 7 & - & - & - & - & - & - \\
\hline Clethra L. & - & - & 1 & 1 & - & - & - & - \\
\hline Clusia L. & 8 & 28 & 2 & 2 & 3 & 4 & 1 & 2 \\
\hline Cyathea Sm. & 2 & 2 & 1 & 21 & - & - & - & - \\
\hline Endlichera C. Presl & 1 & 18 & - & - & - & - & - & - \\
\hline Elaeagia Wedd. & 4 & 12 & 5 & 10 & 5 & 6 & 3 & 8 \\
\hline Eugenia L. & - & - & - & - & 3 & 5 & 1 & 1 \\
\hline Faramea Aubl. & 1 & 3 & - & - & - & - & - & - \\
\hline Ficus L. & - & - & - & - & 2 & 2 & - & - \\
\hline Graffenrieda DC. & 2 & 2 & 2 & 2 & 2 & 8 & - & - \\
\hline Guarea F. Allam. ex L. & - & - & 1 & 1 & - & - & - & - \\
\hline Hedyosmum Sw. & 1 & 36 & - & - & - & - & - & - \\
\hline Helicostylis Trécul & 2 & 14 & 6 & 28 & 3 & 8 & 2 & 3 \\
\hline Hydrangea L. & 1 & 3 & - & - & - & - & - & - \\
\hline Hyeronima Allem. & 2 & 6 & 1 & 1 & 1 & 1 & - & - \\
\hline Mabea Aubl. & 1 & 5 & - & - & - & - & - & - \\
\hline Markea Rich. & - & - & 1 & 2 & - & - & - & - \\
\hline Maytenus Molina & - & - & 1 & 1 & - & - & 1 & 2 \\
\hline Miconia Ruiz \& Pav. & 3 & 8 & 7 & 7 & 12 & 25 & 3 & 4 \\
\hline Mikania Willd. & 1 & 2 & - & - & 1 & 5 & - & - \\
\hline Myrsine L. & 2 & 16 & 1 & 6 & 3 & 8 & 2 & 3 \\
\hline Nectandra Rol. ex Rottb. & 1 & 5 & 3 & 7 & 3 & 8 & 3 & 4 \\
\hline Ocotea Aubl. & - & - & 1 & 1 & - & - & 1 & 1 \\
\hline Palicourea Aubl. & 2 & 19 & 2 & 2 & - & - & 2 & 8 \\
\hline Persea Mill. & - & - & 1 & 1 & - & - & - & - \\
\hline Piper L. & 1 & 2 & - & - & 1 & 3 & - & - \\
\hline Psammisia Klotzsch & 2 & 4 & 5 & 22 & 3 & 4 & 6 & 7 \\
\hline Psychotria L. & 2 & 3 & - & - & 3 & 4 & - & - \\
\hline Ruagea H. Karst. & - & - & 1 & 1 & - & - & - & - \\
\hline Turpinia Vent. & - & - & 1 & 1 & - & - & - & - \\
\hline Fallen tree & 3 & 6 & 3 & 13 & 4 & 8 & 1 & 4 \\
\hline Unidentified liana & 1 & 4 & 2 & 5 & 2 & 5 & - & - \\
\hline Unidentified tree & 1 & 13 & - & - & - & - & 2 & 3 \\
\hline Total & 50 & 239 & 57 & 179 & 51 & 104 & 29 & 52 \\
\hline
\end{tabular}


(mainly because the degree of forest disturbance varies), the high number of orchids that we found on the base of the tree trunks contrasts with other studies, which have reported no orchids or low abundance on this zone (Mehltreter et al. 2005). One explanation for our results could be that the lower canopy density of young trees, especially in early succession stages, allows a greater passage of light to the lower areas, providing better conditions for the establishment of orchids. According to this hypothesis, light intensity may affect tree colonization by orchids. In any case, the lower section of the tree trunks seems to have a great relevance for orchids in this regenerating forest.

The most abundant orchid genus was Stelis Sw. (73.8\%), followed by Epidendrum (8.5\%), Pleurothallis (6.4\%), Lepanthes (3.7\%), Hexisea Lindl. (2.5\%) and Masdevallia (1.9\%). Orchids were not uniformly distributed in the altitudinal range studied. Epidendrum and Lepanthes were more frequent and abundant in lower zone of the fragment. Near $60 \%$ of the Epidendrum and Lepanthes plants were observed at $2200 \mathrm{~m}$. On the other hand, the presence of Pleurothallis and Masdevallia was similar in all the altitudinal range, although their abundance was greater in the higher zone. Thus, the $66.5 \%$ of Pleurothallis plants and the $48.1 \%$ of Masdevallia plants were found at $2250 \mathrm{~m}$. Altitude-related microclimatic factors may be partially responsible for this occurrence pattern, although other environmental factors independent of altitude may also play a role.

Epiphytic orchids were found on 325 of the 1025 recorded trees, shrubs and lianas. The most frequent trees in the fragment were also the ones that had the greatest richness and number of orchids. Of the four genera studied, Pleurothallis occupied the greatest number of trees (57), while Masdevallia was present in only 29 (see Table 1). The average number of individuals per phorophyte was small in all of them (ranging from 4.8 in Epidendrum to 1.8 in Masdevallia), but the variance was large especially in Epidendrum ( \pm 34.8 ) and Pleurothallis $( \pm 16.3)$ (Table $2)$. In order to know how the individuals are distributed among phorophytes, Morisita's index $\left(\mathrm{I}_{\mathrm{M}}\right)$ (Hurlbert 1990) was calculated considering the phorophyte as sampling unit. According to this aggregation index (Table 2), two different patterns were
A

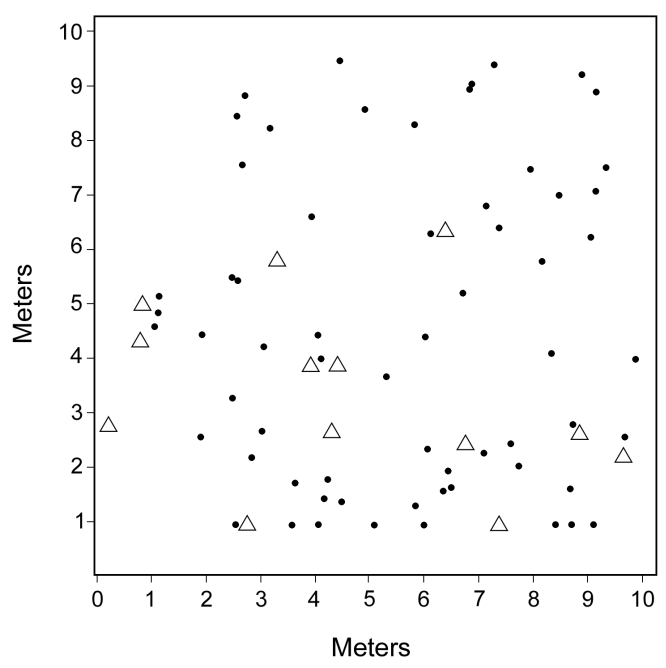

B

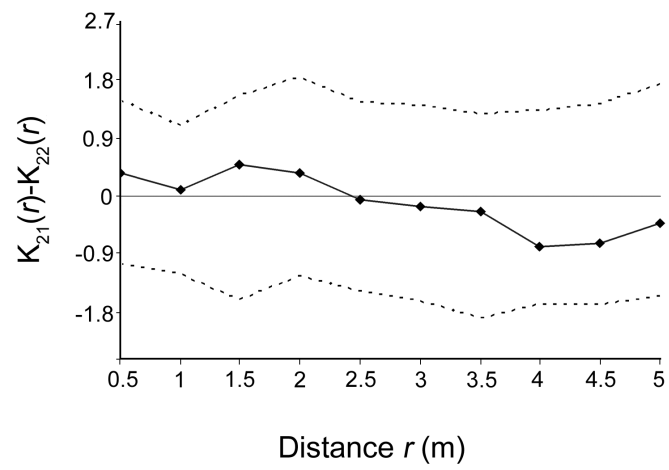

Figure 1. A. Spatial distribution of trees in plot 1 located at $2250 \mathrm{~m}$. Triangles indicate trees with Pleurothallis orchids. B. Bivariate point pattern analysis plotting the $L_{12}$ function across distance. Dotted lines represent the confidence interval of random labelling null hypothesis.

detected: Epidendrum and Pleurothallis plants tended to be clumped ( $\mathrm{I}_{\mathrm{M}}$ values were significantly different from 1), while Lepanthes and Masdevallia plants were randomly distributed. Differences in seed dispersal process may explain this result. Thus, the aggregated pattern observed in Epidendrum and Pleurothallis may be due to limited dispersal ability of their seeds. If this were the case, there would be a higher probability of finding a plant of its same genus in a near-by tree than in a more distant tree. To test this hypothesis, a bivariate point pattern analysis was performed in those plots where the number of phoro- 
TABLE 2. Average number of individuals per host tree (mean \pm variance) and Morisita's index $\left(\mathrm{I}_{\mathrm{M}}\right)$ for Epidendrum, Pleurothallis, Lepanthes or Masdevallia orchids in a secondary montane cloud forest in South Ecuador. Values in parentheses are minimum and maximun. ***: $\mathrm{P}<0.001$.

\begin{tabular}{l|c|c} 
Orchid genus & Individuals per host tree & $\mathbf{I}_{\mathbf{M}}$ \\
\hline Epidendrum & $\begin{array}{c}4.8 \pm 34.8 \\
(1-36)\end{array}$ & $2.32^{* * *}$ \\
\hline Pleurothallis & $\begin{array}{c}3.1 \pm 16.3 \\
(1-21)\end{array}$ & $2.34^{* * *}$ \\
\hline Lepanthes & $\begin{array}{c}2.0 \pm 2.4 \\
(1-7)\end{array}$ & 1.10 \\
\hline Masdevallia & $\begin{array}{c}1.8 \pm 1.3 \\
(1-5)\end{array}$ & 1.09 \\
& & \\
\hline
\end{tabular}

phytes was greater than eight (Diggle 1983, Wiegand $\&$ Moloney 2004). For Pleurothallis, the values of $\mathrm{K}_{21}(r)-\mathrm{K}_{22}(r)$ were inside the confidence interval of the null hypothesis of random labelling for the range of distances 0-5 $\mathrm{m}$ (Figure 1), which means that presence of these orchids is at random. Similar results were obtained for Epidendrum. Thus, since there is no contagious distribution between one phorophyte and nearby trees, seed dispersal in Epidendrum and Pleurothallis is not limited to short distances. This conclusion is also supported by mean distance between phorophytes $(4.0 \pm 5.6 \mathrm{~m}$ for Epidendrum and $4.5 \pm 6.8 \mathrm{~m}$ for Pleurothallis), which is not significantly different than the mean distance between all trees in the plots $(4.7 \pm 2.5 \mathrm{~m})$, and maximum distance to the nearest neighbour $(13.2 \mathrm{~m}$ for Epidendrum and $6.9 \mathrm{~m}$ for Pleurothallis). Other reasons, such as differences in life cycle or reproductive biology could explain the presence of these two distribution patterns.

No phorophyte specificity was observed for any of the epiphytic orchids included in the study. Epidendrum and Pleurothallis grew on more than 20 different genera, and Lepanthes and Masdevallia on more than 10 (see Table 1). Nevertheless, Epidendrum was more frequent on Clusia, Pleurothallis and Lepanthes on Miconia, and Masdevallia on Psammisia. Preference patterns in orchids have also been reported by other authors (Migenis \& Ackerman 1993, Díaz-Santos 2000, and Trapnell \& Hamrick 2006), although the reasons why orchids occur on particular species remain unclear.

The possible effect of phorophyte size on orchid establishment was explored calculating the Spearman's correlation coefficient $\left(r_{\mathrm{S}}\right)$ between DBH and orchid abundance for each of these four genera. No relationship was found in any of them $\left(r_{\mathrm{S}}=-0.12\right.$ $\mathrm{P}=0.42$ for Epidendrum, $r_{\mathrm{S}}=0.15, \mathrm{P}=0.27$ for Pleurothallis, $r_{\mathrm{S}}=0.09 \mathrm{P}=0.52$ for Lepanthes, and $r_{\mathrm{S}}=0.17 \mathrm{P}=0.37$ for Masdevallia), which means phorophyte trunk diameter does not seem to be a crucial factor for orchid colonization. At present, other phorophyte physical characteristics such as bark stability and roughness, and substrate moisture conditions are being investigated.

In conclusion, this study shows the existence of different patterns of presence and abundance depending on each orchid genus. Anyhow, colonization of new trees does not seem to be constrained by limited seed dispersal. Light conditions may be a more important factor for epiphytic orchid establishment than phorophyte identity and size. The abundance of orchids in the lower section of the tree trunks in this regenerating forest is in clear contrast with previous reports made on primary or non-disturbed forests. This outlines the importance of taking into account the different succession states of the forest in which the orchids occur. Finally, although pattern analysis can be helpful in identifying the causes of present spatial structure, additional experimental studies are needed to determine the underlying processes originating these distributions.

Acknowledgements. We thank to Fani Tinitana Imaicela for her help in species identification, and the students Diana Cecilia Guamán and Elizabeth Alexandra Pauta for their field assistance. This work was partially funded by the Universidad Técnica Particular de Loja.

\section{Literature Cited}

Díaz-Santos, F. 2000. Orchid preference for host tree genera in a Nicaraguan tropical rain forest. Selbyana 21(1,2): 25-29.

Diggle, P.J. 1983. Statistical analysis of spatial point patterns. Academic Press, London.

Dodson, C.H. 1994-2003. Native Ecuadorian orchids. 4 v. Colina, Quito.

FAO. 2005. State of the world's forests. Food and Agriculture Organization of the United Nations, Roma.

Goreaud, F. \& R. Pélissier. 2003. Avoiding misinterpretation of biotic interactions with the intertype $K_{12}$-func- 
tion: population independence vs. random labelling hypotheses. J. Veg. Sci. 14: 681-692.

Hurlbert, S.H. 1990. Spatial distribution of the montane unicorn. Oikos 58: 257-271.

Johansson, D. 1974. Ecology of vascular epiphytes in West African rain forest. Acta Phytogeogr. Suec. 59: 1-136.

Mehltreter, K., A. Flores-Palacios \& J.G. García-Franco. 2005. Host preference of low-trunk vascular epiphytes in a cloud forest of Veracruz, Mexico. J. Trop. Ecol. 21: 651-660.

Migenis, L.E. \& J.D. Ackerman. 1993. Orchid-phorophyte relationships in a forest watershed in Puerto Rico. J. Trop. Ecol. 9: 231-240.

Trapnell, D.W. \& J.L. Hamrick. 2006. Variety of phorophyte species colonized by the neotropical epiphyte, Laelia rubescens (Orchidaceae). Selbyana 27(1): 60-64.

Lorena Riofrío and Carlos Naranjo have a teaching position at the Universidad Técnica Particular de Loja, and are presently carrying out their Ph.D. studies in a Conservation Biology program. They are interested in epiphytic orchids of the subtribe Pleurothallidinae, specifically in understanding the spatial genetic structure and the factors that determine their distribution. These studies are oriented to support orchid conservation.

José María Iriondo and Elena Torres are associate profesors of Plant Production and Botany, respectively, at the Universidad Politécnica de Madrid. Their main experience lies on demographic and genetic approaches to plant conservation. In addition to their research on spatial patterns of epiphytic orchids and on the orchid-phorophyte relationships, they participate in a project for the reintroduction of Cypripedium calceolus at the Ordesa and Monte Perdido National Park (Spain). 